\title{
Alternatives to conventional hospitalization for improving lack of access to inpatient beds: A 12-year cross-sectional analysis
}

\author{
Xavier Corbella, Berta Ortiga, Antoni Juan, Nuria Ortega, Carmen Gomez-Vaquero, Cristina \\ Capdevila, I gnasi Bardes, Gilberto Alonso, Carles Ferre, Maria Soler, Rafael Mañez, Eduardo \\ Jaurrieta, Ramon Pujol, Albert Salazar
}

Bellvitge University Hospital and Bellvitge Biomedical Research Institute (IDIBELL), University of Barcelona, L'Hospitalet de Llobregat, Catalonia, Spain

Correspondence: Xavier Corbella. Address: Bellvitge University Hospital, Department of Internal Medicine, Feixa Llarga s/n, 08907 L'Hospitalet de Llobregat, Catalonia, Spain. E-mail: xaviercorbella@yahoo.com

Received: September 29, 2012 Accepted: November 8, 2012

DOI : $10.5430 /$ jha.v2n2p9

URL: http://dx.doi.org/10.5430/jha.v2n2p9

Online Published: December 17, 2012

\section{Abstract}

Background/Objective: When hospitals cannot guarantee available hospital beds for inpatient admission, patients are exposed to prolonged waits, cancellations and diversions that negatively affect their safety and quality of care. The purpose of this study was to evaluate the effect of a multifaceted intervention for eliminating inpatient access delays.

Methods: By using multi-time point cross-sectional analysis, data from all hospitalizations from adult patients registered at an 850-bed public, tertiary-care university hospital were compared from March 1998 to March 2000 (control period) with data from April 2000 to March 2010 (intervention period), after a set of 15 actions for avoiding unnecessary inpatient admissions and to reduce length of hospital stay was implemented by a clinician-administrator taskforce. Response variable was the daily average of "boarded" patients waiting for a hospital bed at 8:00 am in the emergency department (ED). Other measurements included daily contextual and performance hospital variables captured automatically by computer-assisted processes.

Results: Between March 1998 and March 2010, 348,960 consecutive hospitalizations were registered. Despite daily ED visits increasing from 288 (IQR Q1-Q3: 270-309) to 335 patients (IQR Q1-Q3: 306-359; $P<.01$ ), multifaceted intervention reduced the daily emergency "boarded" patients from 7 (IQR Q1-Q3: 3-14) to 3 patients (IQR Q1-Q3: 1-6; $P<.01$ ), and length of hospital stay from 10.9 (IQR Q1-Q3: 9.6-12.5) to 8.1 days (IQR Q1-Q3: 6.8-9.8; $P<.01$ ), while increasing daily scheduled admissions from 32 (IQR Q1-Q3: 17-58) to 63 patients (IQR Q1-Q3: 13-90; $P<.01$ ).

Conclusion: Major changes in hospital procedures for bridging the gap between inpatient and outpatient care by implementing alternatives to conventional hospitalization solved the "inpatient boarding" phenomenon in the ED.

\section{Key words}

Emergency crowding, Hospital admissions, Bed management, Inpatient care, Outpatient care 


\section{Introduction}

Lack of access to inpatient beds is the main factor contributing to hospital crowding worldwide, according to the U.S. Government Accountability Office (GAO)'s 2003 and 2009 and the Institute of Medicine (IOM)'s 2006 reference reports ${ }^{[1-3]}$. Far from being resolved, systematic pressures in health care such as seasonal demands, hospital restructuring, or waiting lists for elective surgery, have led hospitals to a sustained competing bed demand between emergency and scheduled patients for hospital admission ${ }^{[4-10]}$. Hospitalist physicians and the emergency departments (ED) regard the inability for managing this dysfunctional "competition" with enormous concern as they are presented daily with "boarded" patients in the ED hallways, high number of patients placed off-service (meaning that they are sent to a unit corresponding to a different service), lack of available intensive care unit (ICU) beds, theatre cancellations, and hospital diversions ${ }^{\text {[11-17] }}$. All these waits, delays, and cancellations produce a vicious cycle that negatively affects safety and quality of care, exasperating patients and families, overburdening nurses and physicians, and stressing administrators, institutions and governments ${ }^{[18-20]}$. Under such circumstances, hospital executives usually prefer scheduled over emergency admissions, still considering "normal" to force EDs to absorb the excess of demand of the entire hospital. The main reason suggested has been due to emergency admissions tend to be for medical conditions - such as heart or pulmonary failure, and pneumonia - which are considered less profitable than elective surgery ${ }^{[3]}$.

For years hospitals have responded to excess demand by adding more beds, more buildings, and more staff ${ }^{[21-23]}$; however, several experiences have demonstrated that lack of access to inpatient beds is not only a resource problem but that it often reflects a larger failure of hospital-wide operations processes ${ }^{[24-31]}$. In our hospital, strategies to plan for inpatient admissions largely failed during the 1990's. However, in early 2000, a new approach was adopted by a multidisciplinary taskforce installed by the hospital's medical management board. The aim was to implement change in our traditional, "bed-based" inpatient care system, leading executives and clinical staff to work in collaboration to eliminate inpatient "boarding" in the ED, while maintaining elective hospital throughput.

\section{Methods}

\subsection{Setting and design}

The study took place at Bellvitge University Hospital, an 850-bed tertiary-care public institution for adults in the Southern Metropolitan Area of Barcelona, Catalonia, Spain. The hospital provides acute care to a 1.5 million population (excluding pediatrics, obstetrics and burns), and has an active kidney, liver, and heart transplantation program. Staffed by 450 physicians, the hospital registers 33,000 annual inpatient admissions and receives approximately 120,000 emergency patient visits per year. Historically, $10-12 \%$ of the patients registered in the ED are admitted, contributing to approximately $46 \%$ of the hospital's total admissions. Roughly $90 \%$ of the remaining scheduled admissions are surgery patients, totaling approximately 18,000 patients annually.

Before January 2000, our daily hospital operational routine was to face the systematic lack of free available inpatient beds, and how to get the "boarding" of ED admitted patients upstairs, and how to avoid cancellations in elective surgery. At that time, a new hospital board assumed the executive management, asking medical managers and hospitalists, collectively, to implement change in our organizational procedures, prompting us to conduct this long-term, pre-post observational study.

From March 1998 to March 2010, we evaluated the daily tends of the average number of admitted patients waiting for a free inpatient bed in the ED at 8:00 am, and other relevant hospital throughput outcome measures by using a multiple-point cross-sectional analysis design. To facilitate data presentation and statistical analysis, we divided the 12 years of study in six 2-year periods. Period 1, from March 1998 to March 2000, served as the baseline and control period before intervention. From April 2000, the intervention's starting point, to the end of the study in March 2010, Periods 2-6 assessed the impact of outcomes throughout the stepwise implementation of a set of measures. 
The study was designated as exempt by the institutional review board.

\subsection{Multidisciplinary taskforce}

The "Bellvitge Inpatient Flow Improvement Team (BIFIT)" was installed in February 2000. It included clinical staff members and hospital administrators who were urged to work as a collaborative team. The physician group involved the chiefs of the emergency, critical care, medicine, and surgery departments. The medical manager group involved the director of bed management, the nursing director, and the medical director, who was the senior leader of the plan. The chief executive publicly supported these efforts and the team.

The initial components of the BIFIT remained until June 2004, when the medical director, the nursing director, the chief of the ED, the bed director, and the chief executive gradually moved to other hospitals. A new managing board was completely re-installed in July 2005. From January 2008 to the end of the study on March 2010, part of the leader physicians that had actively been enrolled from the onset of the study joined the hospital management to serve as bed director, nursing director, medical director, and chief executive, and assumed the leadership of the plan. The chiefs of critical care, medicine, and surgery departments remained stable throughout the study.

\subsection{Operations management}

During the intervention, operations-research methods and quantitative techniques assisted the BIFIT for analyzing the nuances of the different types of patient flows and inpatient demands and hospital capacities, either controllable (scheduled) or not (emergency). To assess clinical hospital functioning, the BIFIT as well as the rest of the hospital's attending physicians had online access to immediate updating of historical, monthly standardized clinical performance results of patients, either aggregated or individual, especially those related to quality and care efficiency outcomes. For most clinicians, this was the first time that reliable data had been made available on a regular, easily accessible modality.

\subsection{Multifaceted intervention}

In an attempt to assess the measures for improving inpatient access, the BIFIT clarified the unsuccessful procedures and policies attempted prior to the intervention from February to March 2000. The following failures in procedures and policies were identified: 1) consideration of "inpatient boarding" for emergency admissions an "ED" problem (and lack of access to inpatient beds a "resource" one), and not the hospital inability for relieving pressure on hospital bed availability to move patients to floor beds because a larger failure of hospital-wide operations processes; 2) accommodating unscheduled surgeries into the scheduled or to perform later the scheduled permits (instead of to allocate them into separate operating room resources), resulting in theater cancellations or delays, and potentially exposing patients to life-threatening complications; 3) managing inpatient bed admissions in a decentralized form, with hospital occupancy rates of staffed beds over $95-100 \%$, leading to inappropriate unit admission, a subsequent increase in intrahospital transfers, care disruptions, potential medical errors, and longer length of hospital stay; 4) ignoring the knowledge that reducing length of stay and preventing unnecessary admissions, by substituting inpatient to "ambulatory" outpatient care (e.g.: day case treatment), is strongly associated with quality and efficiency gains; 5) disregarding hospital information systems and operation research methodologies to identify patient flow patterns, key performance indicators, and quality outcomes approach.

BIFIT strategies were formulated according to the above mentioned unsuccessful hospital procedures and policies attempted before and previous experiences and recommendations published up to that date ${ }^{[32-44]}$. Interventions were summarized into 15 main actions, focusing on methods to avoid unnecessary admissions and to reduce hospital stay, and for achieving key clinical performance indicators rather than financial outcomes (Table 1). The majority of actions were completely implemented within the first four years after intervention (Periods 2 and 3). Centralized bed management was the cornerstone of the interventions, and the bed director the leader for its implementation. Similarly to the Howell's experience ${ }^{[30]}$, the bed director accountable directly to the medical director, and was staffed daily by an on duty "bed 
director", a hospitalist physician leader freed voluntarily from clinical care responsibilities. Throughout the 12 years of study, the BIFIT met every morning from Monday to Friday at 9:15 am for a short bed briefing to prioritize the free hospital beds expected to become available between the emergency and scheduled inpatient demands.

Table 1. Multifaceted intervention: set of 15 actions (year of implementation)

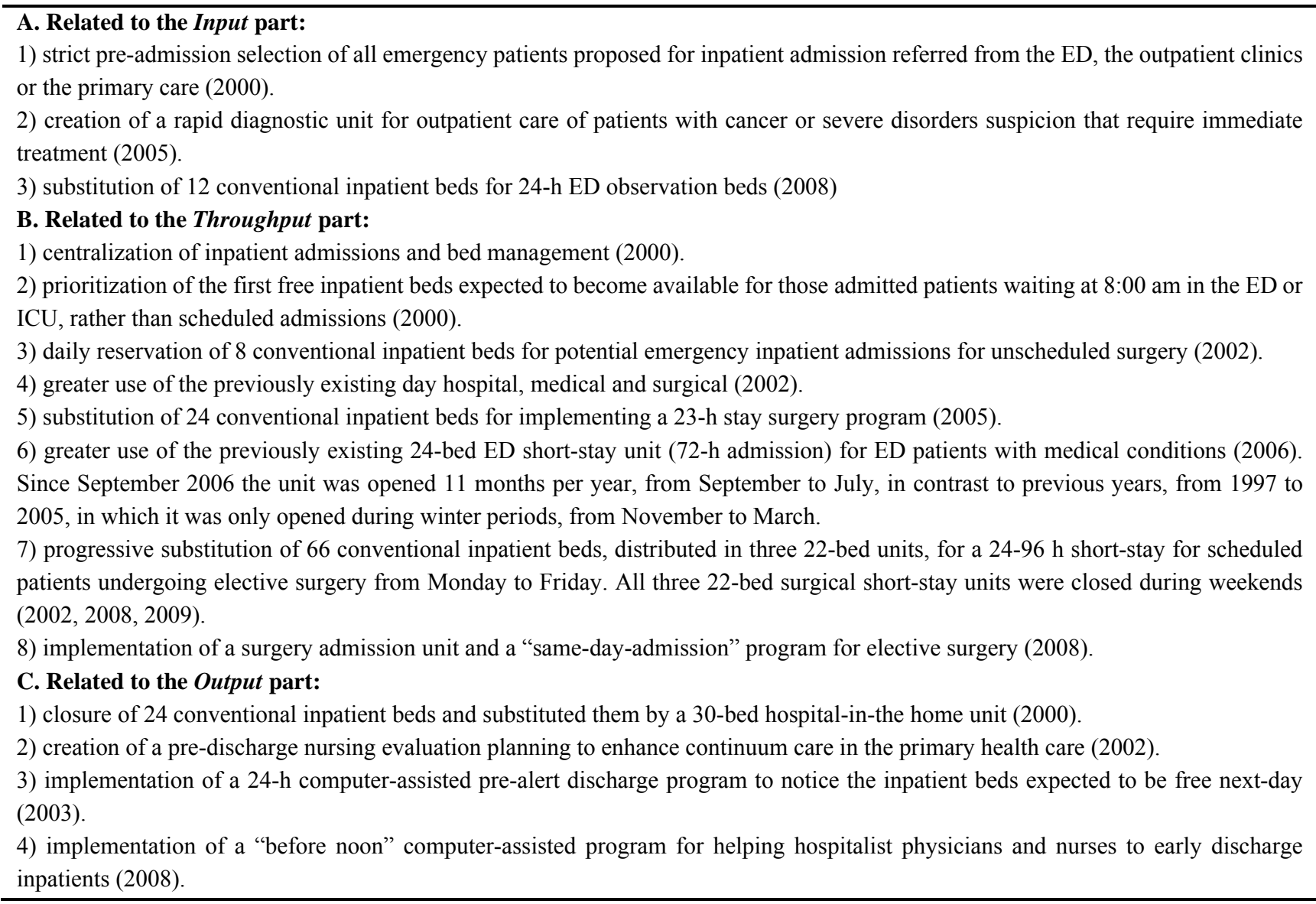

\subsection{Participants and data sources}

All hospitalizations registered in the institutional databases during the study were included. Patient data were collected from various internal information systems. Each observation consisted on the daily measurement of the key performance indicators captured automatically by computer-assisted processes. Specific time stamps capturing the patient's flow progression were available from institutional operational databases, differentiating when an ED admitted patient was ready but waiting to move to an inpatient bed, and when the patient actually left.

\subsection{Outcome measures}

The response variable of the study consisted in the daily number of emergency "boarded" patients waiting for a free inpatient bed at 8:00 am in the ED. Other variables analyzed were classified into two main types: contextual variables and performance variables. Contextual variables included the daily ED visits, daily available hospital beds, daily hospital census, daily occupancy rate, and daily hospitalized patients placed out of service. Performance variables were the daily hospitalized patients admitted from the ED, daily ED visits resulting in hospital admission, daily scheduled inpatient admissions, daily scheduled patients admitted for 23-h surgery, daily scheduled patients admitted the same day of surgery, daily ED patients transferred to another hospital, daily patients admitted at the hospital-in-the home unit, and daily mean 
length of stay of discharged patients (defined as the mean length of stay of all patients discharged during that day in particular). As our analysis included the entire hospital patient population between March 1998 and March 2010, the matter of sample size calculation was irrelevant.

\subsection{Statistical analysis}

To describe categorical variables, the total number of cases ( $\mathrm{N}$, days) and the percentage of each category were used in the descriptive univariate and bivariate analysis. For continuous variables, the medium and the interquartile range (IQR: Q1-Q3) were used to adjust for lack of normality. For bivariate analysis, we used the Chi-square test for categorical variables and the nonparametric Mann-Whitney test for categorical variables. Statistical significance for these tests was set to $p<.05$. We used a Poisson regression model with logistic link to test a statistical model of the data. First, univariate models were assessed for the response variable. Poisson modeling generates the following statistics: estimated $\beta$ with the Wald confidence interval at $95 \%$, Odds Ratio (OR) with confidence interval at $95 \%$ and $p$-value.

Table 2. Outcome Measures: Contextual and Performance Variables * (March 1998 - March 2010)

\begin{tabular}{|c|c|c|c|c|c|c|}
\hline Variables & $\begin{array}{l}\text { Period } 1 \\
\text { March } 1998 \text { - } \\
\text { March } 2000\end{array}$ & $\begin{array}{l}\text { Period } 2 \\
\text { April } 2000 \text { - } \\
\text { March } 2002\end{array}$ & $\begin{array}{l}\text { Period } 3 \\
\text { April } 2002 \text { - } \\
\text { March } 2004\end{array}$ & $\begin{array}{l}\text { Period } 4 \\
\text { April } 2004 \text { - } \\
\text { March } 2006\end{array}$ & $\begin{array}{l}\text { Period } 5 \\
\text { April } 2006 \text { - } \\
\text { March } 2008\end{array}$ & $\begin{array}{l}\text { Period } 6 \\
\text { April } 2008 \text { - } \\
\text { March } 2010\end{array}$ \\
\hline $\begin{array}{l}\text { Median of daily ED patients } \\
\text { waiting for a bed at 8:00 am } \\
{[\mathrm{IQR}] \dagger}\end{array}$ & $7[3-14]$ & $8[3-14]$ & $3[1-7]$ & $1[0-2]$ & $2[0-8]$ & $3[1-6]$ \\
\hline $\begin{array}{l}\text { Days without ED patients } \\
\text { waiting for a bed at 8:00 } \mathrm{AM}(\%)\end{array}$ & $78(9.5)$ & $51(7.0)$ & $116(15.9)$ & $353(48.4)$ & $206(28.2)$ & $117(16.0)$ \\
\hline Median of daily ED visits [IQR] & 288 [270-309] & 305 [285-326] & 318 [295-340] & 335 [311-359] & $343[319-365]$ & 335 [306-359] \\
\hline $\begin{array}{l}\text { Median of daily emergency } \\
\text { admissions [IQR] }\end{array}$ & 34 [29-40] & $32[27-37]$ & $32[27-37]$ & 34 [29-39] & $35[31-40]$ & $35[31-40]$ \\
\hline $\begin{array}{l}\text { Median of daily emergency } \\
\text { admissions rate } \$[\mathrm{IQR}]\end{array}$ & $11.9[9.9-13.7]$ & $10.4[8.9-12.2]$ & $9.9[8.6-11.6]$ & $10.2[8.7-11.7]$ & $10.4[8.9-11.8]$ & $10.6[9.2-12.2]$ \\
\hline $\begin{array}{l}\text { Median of daily scheduled } \\
\text { admissions [IQR] }\end{array}$ & $32[17-58]$ & $33[15.5-60]$ & 37 [18-69] & $52.5[23-82]$ & $56.5[20-84.5]$ & $63[13-90]$ \\
\hline $\begin{array}{l}\text { Median of daily available } \\
\text { hospital beds [IQR] }\end{array}$ & 827 [788-867] & 819 [763-863] & 805 [741-845] & $774[722-808]$ & 750 [703-787] & 767 [714-812] \\
\hline $\begin{array}{l}\text { Median of daily hospital } \\
\text { occupancy rate [IQR] }\end{array}$ & $95.5[91.2-99.5]$ & $94.6[90.9-96.3]$ & $92.2[88.7-94.2]$ & $89.7[85.8-92.8]$ & $92.4[89-94.8]$ & 89.4 [86.1-91.9] \\
\hline $\begin{array}{l}\text { Median of daily inpatients } \\
\text { placed out of service [IQR] }\end{array}$ & $162[150-171]$ & $71[66-80]$ & $59[51-66]$ & $53[46-61]$ & $70[56-78]$ & 62 [49-69] \\
\hline Median length of stay $\S[\mathrm{IQR}]$ & $10.9[9.6-12.5]$ & $10.1[8.9-11.7]$ & $9.3[8-10.8]$ & $8.6[7.5-10.1]$ & $8.6[7.1-10.1]$ & $8.1[6.8-9.8]$ \\
\hline $\begin{array}{l}\text { Median pre-surgery length of } \\
\text { stay } ₫[\mathrm{IQR}]\end{array}$ & $1.4[1.2-1.7]$ & $1.3[1.2-1.5]$ & $1[0.9-1.2]$ & $0.8[0.7-1]$ & $0.65[0.6-0.75]$ & $0.45[0.4-0.5]$ \\
\hline $\begin{array}{l}\text { Median length of stay of } \\
\text { emergency admissions [IQR] }\end{array}$ & $13.9[12-15.8]$ & $13.6[11.7-15.7]$ & $13.1[11.4-15.1]$ & $12[10.2-14.1]$ & $11.8[9.9-14]$ & $11.5[9.7-13.5]$ \\
\hline $\begin{array}{l}\text { Median length of stay of } \\
\text { scheduled admissions } \S[\mathrm{IQR}]\end{array}$ & $7.8[6.4-10]$ & $6.6[5.4-8.4]$ & $5.8[4.6-7.5]$ & $5.2[4.2-6.6]$ & $4.9[3.7-6.5]$ & $4.7[3.6-6.3]$ \\
\hline
\end{tabular}

* All variables reached statistical signification $(P<.05) ; \dagger \mathrm{IQR}=$ Interquartile range; $¥$ Proportion of ED patients resulting in hospital admission; $\S$ Surgical patients with $\leq 23$-h of hospital stay were not included

\section{Results}

Between March 1998 and March 2010, we identified 348,960 hospitalizations from all adult patients registered in our institutional databases. The implementation of the set of 15 actions (Table 1) resulted in a progressive and sustained significant decline in the daily mean number of ED admitted patients waiting for a free inpatient bed in our ED at 8:00 am (Figure 1). At the end of the study, results showed that the hospital functioned daily with no "boarded" admitted patients in 
the ED, or with a very low number of them who technically remained in the ED by gender reasons, since $90 \%$ of our hospital rooms are double only.

Figure 1. Monthly patients waiting for a free hospital bed in the ED at 8:00 am

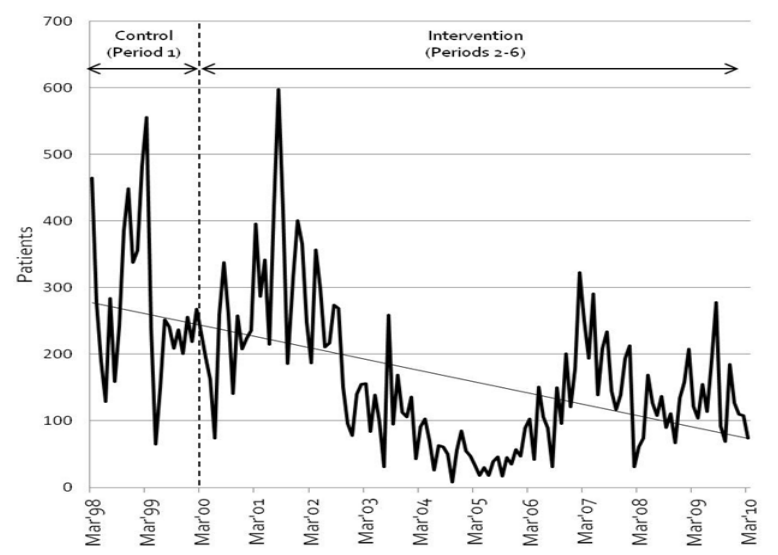

Table 3. Evolution of Hospital Diversions from the ED and Use of Main Alternatives to Traditional Hospitalization

\begin{tabular}{|c|c|c|c|c|c|c|}
\hline & $\begin{array}{l}\text { Period } 1 \\
\text { March } 1998 \text { - } \\
\text { March } 2000\end{array}$ & $\begin{array}{l}\text { Period } 2 \\
\text { April } 2000 \text { - } \\
\text { March } 2002\end{array}$ & $\begin{array}{l}\text { Period } 3 \\
\text { April } 2002 \text { - } \\
\text { March } 2004\end{array}$ & $\begin{array}{l}\text { Period } 4 \\
\text { April } 2004 \text { - } \\
\text { March } 2006\end{array}$ & $\begin{array}{l}\text { Period } 5 \\
\text { April } 2006 \text { - } \\
\text { March } 2008\end{array}$ & $\begin{array}{l}\text { Period } 6 \\
\text { April } 2008 \text { - } \\
\text { March } 2010\end{array}$ \\
\hline $\begin{array}{l}\text { Hospital Diversions from } \\
\text { the ED }\end{array}$ & 2332 & 4136 & 5368 & 1842 & 650 & 276 \\
\hline $\begin{array}{l}\text { Medium Day-Surgery } \\
\text { admissions (IQR: Q1-Q3) }\end{array}$ & - & - & - & $10(0-18)$ & $13(0-22)$ & $16(0-24)$ \\
\hline $\begin{array}{l}\text { Medium Hospital at home } \\
\text { admissions (IQR: Q1-Q3) }\end{array}$ & - & - & $1(1-2)$ & $2(1-2)$ & $2(1-3)$ & $2(1-3)$ \\
\hline $\begin{array}{l}\text { Patients admitted in ED } \\
\text { short-stay unit }\end{array}$ & 2300 & 1150 & 1380 & 3795 & 4370 & 3610 \\
\hline $\begin{array}{l}\text { Patients attended to } \\
\text { outpatient clinics }\end{array}$ & 701664 & 742310 & 812152 & 836890 & 889284 & 995182 \\
\hline $\begin{array}{l}\text { Rapid outpatient diagnostic } \\
\text { unit }\end{array}$ & - & - & - & 555 & 1160 & 1203 \\
\hline ED Observation Unit & - & - & - & - & 2771 & 4525 \\
\hline
\end{tabular}

Table 2 shows that the major reduction in the daily average of "boarded" patients in the ED at 8:00 am and the greatest proportion of days - almost $50 \%$ - without "inpatient boarding" phenomenon in the ED was achieved in the middle phase of intervention (Period 4), when compared with baseline (Period 1). Although a slight increase was documented during the last follow-up phases (Periods 5 and 6), a very low mean number of "boarded" remained daily in the ED at the end of the study on March 2010. Table 2 also summarizes the impact of interventions in other key patient flow indicators. Although daily ED visits clearly increased throughout the 12 years studied, the implementation of a strict pre-admission selection process for emergency admissions reduced the daily proportion of ED visits resulting in hospital admission, especially during the first 4 years after intervention (Periods 2-3), maintaining stable the absolute number of daily 
emergency inpatient admissions. These outcomes were largely sustained until the end of the study, although a small increase was observed from Period 4 to 6. Simultaneously, scheduled hospital throughput significantly increased throughout the overall study. This increase was mostly due to elective surgical activity, $20 \%-25 \%$ of them admitted through the "same-day-admission program" launched from Period 5.

Reducing mean length of inpatient stay was an essential goal to alleviate pressure on hospital bed availability. Table 2 shows the sharp reduction observed after intervention which reached statistical significance. Interestingly, length of hospital stay was reduced from both scheduled and emergency admissions, although of great relevance was the reduction achieved among emergency admissions, known to be those with usual longer hospital stay. This reduction in the length of stay led the hospital to a lower occupancy rate despite a significant reduction of available hospital beds. Table 3 shows the progressive increasing use of main alternatives of traditional hospitalization, and reduction in hospital diversions from the ED throughout the study. Table 4 shows the regression results.

The comparison between Periods 1 and 6 showed a progressive significantly higher complexity of the case-mix of patients admitted, with a mean of the Diagnosis-Related Groups (DRG) relative weights that increased from 1.445 to 2.467. Significantly, the mortality rate decreased from $5.2 \%$ to $4.4 \%$ between Periods 1 and 6 , although the urgent readmissions rate during the first 30 days also increased from $4 \%$ to $5.4 \%$.

Table 4. Incidence rate ratios from Poisson Regression

\begin{tabular}{lll}
\hline Variable & Incidence Rate Ratio (95\% IC) & $P$ \\
\hline Periods & 1 & - \\
March 1998 - March 2000 (reference) & $0.995(0.960-1.032)$ & 0.80 \\
April 2000 - March 2002 & $0.560(0.537-0.585)$ & $<0.001$ \\
April 2002 - March 2004 & $0.192(0.180-0.205)$ & $<0.001$ \\
April 2004 - March 2006 & $0.564(0.540-0.589)$ & $<0.001$ \\
April 2006 - March 2008 & $0.480(0.459-0.503)$ & $<0.001$ \\
April 2008 - March 2010 & $0.997(0.996-0.997)$ & $<0.001$ \\
Median of daily ED visits & $1.041(1.037-1.045)$ & $<0.001$ \\
Median length of stay of scheduled admissions & $1.046(1.042-1.050)$ & $<0.001$ \\
Median length of stay of emergency admissions & $1.067(1.062-1.073)$ & $<0.001$ \\
Median length of stay * & $1.005(1.004-1.005)$ & $<0.001$ \\
Median of daily hospitalized patients & $1.003(1.002-1.003)$ & $<0.001$ \\
Median of daily scheduled admissions $*$ & $1.056(1.036-1.076)$ & $<0.001$ \\
Median of daily hospital-in-the-home admissions & $0.983(0.981-0.985)$ & $<0.001$ \\
Median of daily emergency admissions & $0.977(0.974-0.981)$ & $<0.001$ \\
Median of daily hospital diversions & $1.108(1.105-1.111)$ & $<0.001$ \\
Median of hospital occupancy rate & $1.002(1.001-1.002)$ & $<0.001$ \\
Median of daily available hospital beds &
\end{tabular}

* Surgical patients with $\leq 23$-h of hospital stay were not included

\section{Discussion}

Before the intervention in April 2000, our hospital had unsuccessfully deployed several policies to address crowding and barriers to inpatient access, raising the same idea of many hospitals that the problem was intractable. An effective approach required the collaboration among clinicians and administrators. The implementation of the intervention was hospital-wide, based on science and data driven, and it aimed at causes rather than symptoms. Furthermore, it included a 10 -year systematic compliance review and enforcement process. To our knowledge, this study is the longest and largest 
comprehensive investigation demonstrating successful strategies for eliminating the "inpatient boarding" phenomenon from the ED whilst improving hospital elective throughput at a public, metropolitan, tertiary-care hospital setting.

Although initial efforts were mainly directed towards eliminating "inpatient boarding" in the ED ${ }^{[45]}$, we were strongly convinced that this phenomenon was a symptom of a larger, hospital system-level problem ${ }^{[46,47]}$. Addressing the other largely hidden causes were possible due to the firm support and commitment of physician leaders and medical executives who worked together to develop an improved understanding of the underlying causes of the problem and how best to rectify it. Ultimately, our study revealed that a too stagnant, "bed-based" policy and departmentally oriented hospital operational procedures need to be modified. During the 10-year follow-up period after intervention, resistance to change was possibly less than previous attempts because of clinicians and administrators worked in collaborative approach. On one hand, the medical director clearly advocated that improving patient flow was a collective priority, and the bed director tirelessly applied the set of interventions. On the other, the department chiefs ensured the clinical efficacy and safety of actions applied, pulling the rest of hospitalist physicians for implementing change at local level. The transparency of measurements regularly reported allowed clinicians and administrators to openly question the traditional "bed-based" clinical practice and promoting successful change strategies.

For optimizing patient flow, we decided to relieve pressure on hospital bed availability by both preventing unnecessary admissions and reducing length of hospital stay. In accordance, our option was not to add more beds, but to strongly reinforce a greater use of alternatives to standard hospitalization, either already existing or new, either for emergency or scheduled patients, either surgical or medical ${ }^{[31,48-51]}$. This was not a financially-motivated efficiency goal, but certainly a clinically-inspired intervention for a more appropriate use of our inpatient beds. A significant improvement on hospital capacity, as well as on quality and patient care outcomes was showed very early after intervention. In consequence, the daily census of hospitalized patients significantly decreased throughout the decade of sustained intervention, and a substantial number of hospital beds could be progressively reduced whilst hospital throughput strikingly increased.

In addition to the widely cited GAO and IOM reports ${ }^{[1-3]}$, much has been published during this decade of study showing the spread of crowding and access block worldwide, particularly at large metropolitan and urban hospitals, and how it may negatively affect patient quality outcomes $[15,19,52,53]$. Moreover, a variety of interesting consensus documents recommending how to improve patient flow have also been published ${ }^{[54-58]}$. However, evidence-based experiences testing these strategies are still very limited to date ${ }^{[15,16]}$, being the uniform conclusion of most of them that it's all about to increase the number of available inpatient beds, while waiting for system-wide solutions ${ }^{[23,59-61]}$.

In the meantime, some hospitals have recognized that "inpatient boarding" and access block are mainly a symptom of a hidden hospital broad operational trouble, deploying several strategies for a better management of hospital beds, as opposed to simply increasing the number of them ${ }^{[26,62-66]}$. Furthermore, there are other remarkable clinician-led experiences improving barriers to inpatient access after deploying multifaceted, multidisciplinary and hospital wide interventions for changing hospital systems ${ }^{[67-72]}$. Unfortunately, in most of them, interventions were of short duration or had short term impact, being the common challenge how to sustain change over the longer term.

\section{Limitation}

Our research design was a long-term observational study with multiple-time point cross-sectional analyses. As such, the impact of the multipronged intervention implemented was compared before and after, but cause and effect of individual variables could not be established. Multi-time point cross-sectional analysis only determines that there is an association between exposures and outcomes, which suggests potential correlations and points at areas for further studies. Results are a snapshot giving insight into which may be correct, but they don't provide support for causal relationships. Furthermore, cross-sectional analysis cannot rule out interactions or external influences. In our study, in addition to the set of interventions implemented, other initiatives in the hospital or trends in the broader health care community might be 
impacting our data during the decade of investigation, such as the adoption of new and cost-effective treatments and technologies, the use of measures intended to reduce errors and increase quality, the financial pressure, the competition and other market forces, the performance monitoring, the effective leadership, and the new management culture between clinicians and hospital administrators. Despite these limitations, results demonstrated that other important external events would not favor the post-intervention periods, since the hospital bed capacity decreased, ED visits increased, DRG relative weight increased, hospital diversions decreased and regional volume of beds for inpatients requiring placement to chronic care or nursing home facilities remained stable.

\section{Conclusion}

Managing the fateful trend towards hospital crowding remains an extremely complex challenge worldwide that requires leadership, science, and time. At hospital level, clinicians and administrators must face this issue in collaboration, leading a thorough reengineering of hospital operational procedures. In our experience, a firm and sustained bet for using alternatives to traditional "bed-based" inpatient care eliminated the "inpatient boarding" phenomenon from the ED, and improved significantly the overall hospital elective throughput. Thus, the overall long-term cost savings and clinical gains to patient quality of care outcomes amply compensated the alleged initial costs for applying the set of measures. Interestingly, results still remain today in the organization beyond the particular people who led the plan during more than a decade throughout. Now the challenge is how to disseminate these measures to other hospitals, encouraging other hospitalist and executive groups for testing them and, possibility, scale up to the state or national levels, via policy or regulatory changes.

\section{Conflict of interests}

The authors declare that they have no competing interests or conflict of interests.

\section{Authors' contributions}

$\mathrm{XC}$ and $\mathrm{AS}$ conceived the study; $\mathrm{BO}, \mathrm{NO}$ and MS designed the cross-sectional analyses and provided statistical advice on study design; AJ, CGV, CC, IB, GA and CF made substantial contributions to design and supervise the conduct of the intervention, and the collection of the data; $\mathrm{BO}, \mathrm{NO}$, and MS managed and analyzed the data, including quality control; RM, EJ and RP undertook recruitment of participating departments and revised the manuscript critically for important intellectual content; XC and AS, drafted the manuscript. All authors contributed substantially to its revision, and approved the final manuscript (including revisions) and took public responsibility for it.

\section{Authors' information}

XC (M.D., Ph.D., M.B.A.) is Clinical Chief at the Department of Internal Medicine and CEO of the Bellvitge University Hospital-IDIBELL, Feixa llarga s/n, 08907 L'Hospitalet de Llobregat, Barcelona, Catalonia, Spain. XC is also associate professor at the Institute of Public Health and Health Policy, School of Medicine, International University of Catalonia, Barcelona, Catalonia, Spain. BO (M.D., M.B.A.), CGV (M.D., Ph.D.), and CC (M.D.) are with the Medical Direction, Bellvitge University Hospital-IDIBELL, Barcelona, Catalonia, Spain. NO (M.Sc.) is with the Faculty of Mathematics and Statistics, Universitat Politecnica de Catalunya - Barcelona Tech, Barcelona, Catalonia, Spain. AJ (M.D., Ph.D.), IB (M.D.), GA (M.D.) and CF (M.D., Ph.D.) are with the Department of Emergency Medicine, Bellvitge University Hospital-IDIBELL, Barcelona, Catalonia, Spain. MS (M.D., Ph.D.) is Senior Consultant at the Department of Information and Benchmarking Solutions (IASIST, SA), Barcelona, Catalonia, Spain. RM (M.D., Ph.D.), is Chief of the Department of Critical Care, Bellvitge University Hospital-IDIBELL, Barcelona, Catalonia, Spain. RP (M.D., Ph.D.), is Chief of the Department of Internal Medicine, Bellvitge University Hospital-IDIBELL, Barcelona, Catalonia, Spain. RP is also professor at the Department of Clinical Sciences, School of Medicine, University of Barcelona, Barcelona, Catalonia, Spain. AS (M.D., Ph.D), is Chief of the Emergency Department and Medical Director of the Bellvitge University 
Hospital-IDIBELL, Barcelona, Catalonia, Spain. AS is also associate professor at the Department of Clinical Sciences, School of Medicine, University of Barcelona, Barcelona, Catalonia, Spain.

\section{Acknowledgements and funding}

We are indebted to all the nurses, hospitalists and emergency physicians providing care for the patients at Bellvitge University Hospital during the study without which the plan could not have progressed. Past members of the hospital's medical board Dr. Joan Escarrabill, Dr. Rosa Ramon, and Dr. Pere Soley, who publicly supported the Bellvitge Inpatient Flow Improvement Team (BIFIT) for implementing change, are also gratefully acknowledged.

No external funding was received to support this study. Basic financial research support was only provided by the hospital management board to the medical director, who was the senior leader of the research plan.

\section{References}

[1] U.S. Government Accountability Office. Hospital Emergency Departments: Crowded Conditions Vary among Hospitals and Communities, GAO-03-460 (Washington D.C.: March 14, 2003).

[2] U.S. Government Accountability Office. Hospital Emergency Departments: Crowding Continued to Occur, and Some Patients Wait Longer than Recommended Time Frames, GAO-09-347 (Washington, D.C.: April 30, 2009).

[3] Institute of Medicine. Committee on the Future Emergency Care in the United States Health System. Hospital-Based Emergency Care: At the Breaking Point. Washington DC: National Academics Press; 2007.

[4] Andrulis DP, Kellermann A, Hintz EA, Hackman BB, Weslowski VB. Emergency departments and crowding in United States teaching hospitals. Ann Emerg Med. 1991; 20: 980-6. http://dx.doi.org/10.1016/S0196-0644(05)82976-2

[5] Henry MC. Overcrowding in America's emergency departments: inpatient wards replace emergency care. Acad Emerg Med. 2001; 8: 188-189. PMid:11157298 http://dx.doi.org/10.1111/j.1553-2712.2001.tb01287.x

[6] Schull MJ, Szalai JP, Schwartz B, Redelmeier DA. Emergency department overcrowding following systematic hospital restructuring: trends at twenty hospitals over ten years. Acad Emerg Med. 2001; 8: 1037-1043. PMid:11691665 http://dx.doi.org/10.1111/j.1553-2712.2001.tb01112.x

[7] Forster AJ, Stiell I, Wells G, Lee AJ, van Walraven C. The effect of hospital occupancy on emergency department length of stay and patient disposition. Acad Emerg Med. 2003; 10: 127-133. PMid:12574009 http://dx.doi.org/10.1111/j.1553-2712.2003.tb00029.x

[8] Kroneman M, Siegers JJ. The effect of hospital bed reduction on the use of beds: a comparative study of 10 European countries. Soc Sci Med. 2004; 59: 1731-1740. PMid:15279929 http://dx.doi.org/10.1016/j.socscimed.2004.01.036

[9] Langhan TS. Do elective surgical and medical admissions impact emergency department length of stay measurements?. Clin Invest Med. 2007; 30: E177-182. PMid:17892759

[10] Levin S, Dittus R, Aronsky D, Weinger M, France D. Evaluating the effects of increasing surgical volume on emergency department patient access. BMJ Qual Saf. 2011; 20: 146-152. PMid:21209127 http://dx.doi.org/10.1136/bmjqs.2008.030007

[11] Derlet RW. Overcrowding in emergency departments: increased demand and decreased capacity. Ann Emerg Med. April 2002; 39: 430-432. PMid:11919530 http://dx.doi.org/10.1067/mem.2002.122707

[12] Forero R, Hillman K, McCarthy S, Fatovich D, Joseph A, Richardson DW. Access block and ED overcrowding. Emerg Med Australas. 2010; 22: 119-135. PMid:20534047 http://dx.doi.org/10.1111/j.1742-6723.2010.01270.x

[13] Baker DW, Stevens CD, Brook RH. Patients who leave a public hospital emergency department without being seen by a physician. JAMA. 1991; 266: 1085-1090. PMid:1865540 http://dx.doi.org/10.1001/jama.1991.03470080055029

[14] Kellermann AL. Crisis in the Emergency Department. N Eng J Med. 2006; 355: 1300-1303. PMid:17005946 http://dx.doi.org/10.1056/NEJMp068194

[15] Hoot NR, Aronsky D. Systematic review of emergency department crowding: causes, effects, and solutions. Ann Emerg Med. 2008; 52: 126-136. PMid:18433933 http://dx.doi.org/10.1016/j.annemergmed.2008.03.014

[16] Forero R, McCarthy S, Hillman K. Access block and emergency department overcrowding. Crit Care. 2011; 15: 216. Epub 2011 Mar 22. PMid:2145750 http://dx.doi.org/10.1186/cc9998

[17] Kellermann AL, Martinez R. The ER, 50 years on. N Eng J Med. 2011; 364: 2278-2279. PMid:21675886

http://dx.doi.org/10.1056/NEJMp1101544 
[18] Miró O, Antonio MT, Jiménez S, De Dios A, Sánchez M, Borrás A, et al. Decreased health care quality associated with emergency department overcrowding. Eur J Emerg Med. 1999; 6: 105-107. PMid:10461551

http://dx.doi.org/10.1097/00063110-199906000-00003

[19] Derlet RW, Richards JR. Overcrowding in the nation's emergency departments: complex causes and disturbing effects. Ann Emerg Med. 2000; 3: 63-68. http://dx.doi.org/10.1016/S0196-0644(00)70105-3

[20] Salazar A, Bardés I, Juan A, Olona N, Sabido M, Corbella X. High mortality rates from medical problems of frequent emergency department users at a university hospital tertiary care centre. Eur J Emerg Med. 2005; 12: 2-5. PMid:15674076 http://dx.doi.org/10.1097/00063110-200502000-00002

[21] Mace SE, Graff L, Mikhail M, Ross M. A national survey of observation units in the United States. Am J Emerg Med. 2003; 21: 529-533. PMid:14655230 http://dx.doi.org/10.1016/j.ajem.2003.08.012

[22] Han JH, Zhou C, France DJ, Zhong S, Jones I, Storrow AB, et al. The effect of emergency department expansion on emergency department overcrowding. Acad Emerg Med. 2007; 14: 338-343. PMid:17400996 http://dx.doi.org/10.1111/j.1553-2712.2007.tb02018.x

[23] Fatovich DM, Hughes G, McCarthy SM. Access block: it's all about available beds. Med J Aust. 2009; 190: $362-363$. PMid:19351309

[24] Cardin S, Afilalo M, Lang E, Collet JP, Colacone A, Tselios C, et al. Intervention to decrease emergency department crowding: does it have an effect on return visits and hospital readmissions?. Ann Emerg Med. 2003; 41: 173-185. PMid:12548266 http://dx.doi.org/10.1067/mem.2003.50

[25] Cameron PA, Campbell DA. Responses to access block in Australia: Royal Melbourne Hospital. Med J Aust. 2003; $178: 109-110$. PMid:12558479

[26] Asplin BR, Magid DJ. If you want to fix crowding, start by fixing your hospital. Ann Emerg Med. 2007; 49: $273-274$. PMid:17317503 http://dx.doi.org/10.1016/j.annemergmed.2007.01.012

[27] Levin SR, Dittus R, Aronsky D, Weinger MB, Han J, Boord J, et al. Optimizing cardiology capacity to reduce emergency department boarding: a systems engineering approach. Am Heart J. 2008; 156: 1202-1209. PMid:19033021 http://dx.doi.org/10.1016/j.ahj.2008.07.007

[28] Frost SA, Alexandrou E, Bogdanovski T, Salamonson Y, Parr MJ, Hillman KM. Unplanned admission to intensive care after emergency hospitalisation: Risk factors and development of a nomogram for individualised risk. Resuscitation. $2009 ; 80: 22$. PMid:19084319 http://dx.doi.org/10.1016/j.resuscitation.2008.10.030

[29] Khare RK, Powell ES, Reinhardt G, Lucenti M. Adding more beds to the emergency department or reducing admitted patient boarding times: which has a more significant influence on emergency department congestion?. Ann Emerg Med. 2009; 53: 575-585. PMid:18783852 http://dx.doi.org/10.1016/j.annemergmed.2008.07.009

[30] Howell E, Bessman E, Kravet S, Kolodner K, Marshall R, Wright S. Active bed management by hospitalists and emergency department throughput. Ann Intern Med. 2008; 149: 804-810. PMid:19047027

[31] Corbella X, Salazar A, Pujol R. Major ambulatory medicine. Eur J Intern Med. 2012. http://dx.doi.org/10.1016/j.ejim.2012.09.003.

[32] Feferman I, Cornell C. How we solved the overcrowding problem in our emergency department. CMAJ. 1989; 140: $273-276$. PMid:2914239

[33] Fincke BG, Gaehde SA, Rubins HB. The medical day hospital. A new concept in ambulatory medical education. Arch Intern Med. 1990; 150: 533-536. PMid:2310272 http://dx.doi.org/10.1001/archinte.1990.00390150043008

[34] Lynn SG, Kellermann AL. Critical decision making: managing the emergency department in an overcrowded hospital. Ann Emerg Med. 1991; 20: 287-292. http://dx.doi.org/10.1016/S0196-0644(05)80942-4

[35] McClaran J, Tover Berglas R, Glass KC. Chronic status patients in a university hospital: bed day utilization and length of stay. CMAJ. 1991; 145: 125-165.

[36] Mamon J, Steinwachs DM, Fahey M, Bone LR, Oktay J, Klein L. Impact of hospital discharge planning on meeting patient needs after returning home. Health Serv Res. 1992; 27: 155-175. PMid:1317367

[37] Welsh F. Accounting for the transition from inpatient to outpatient surgery. Physician Exec. 1995; 21: 16-19. PMid:10172630

[38] Coast J, Inglis A, Morgan K, Gray S, Kammerling M, Frankel S. The hospital admissions study in England: are there alternatives to emergency hospital admission? J Epidemiol Community Health. 1995; 49: 194-199. PMid:7798050 http://dx.doi.org/10.1136/jech.49.2.194

[39] Smith CB, Goldman RL, Martin DC, Williamson J, Weir C, Beauchamp C, et al. Overutilization of acute-care beds in Veterans Affairs hospitals. Med Care. 1996; 34: 85-96. PMid:8551814 http://dx.doi.org/10.1097/00005650-199601000-00007

[40] Shepherd G, Beadsmoore A, Moore C, Hardy P, Muijen M. Relation between bed use, social deprivation, and overall bed availability in acute adult psychiatric units, and alternative residential options: a cross sectional survey, one day census data, and staff interviews. BMJ. 1997; 314: 262-266. PMid:9022489 http://dx.doi.org/10.1136/bmj.314.7076.262 
[41] Wanklyn P, Hosker H, Pearson S, Belfield P. Slowing the rate of acute medical admissions. J R Coll Physicians Lond. 1997; 31 : 173-176. PMid:9131518

[42] Morgan C, Vaughan L. Managing admissions. Bed spreads. Health Serv J. 1997; 107: 28-29. PMid:10176079

[43] Hensher M, Fulop N, Coast J, Jefferys E. The hospital of the future. Better out than in? Alternatives to acute hospital care. BMJ. 1999; 319: 1127-1130. PMid:10531112 http://dx.doi.org/10.1136/bmj.319.7217.1127

[44] McLaren EH, Summerhill LE, Miller WJ, McMurdo ML, Robb CM. Re-organising emergency medical admitting: the Stobhill experience, 1992-1997. Health Bull (Edinb). 1999; 57: 108-117.

[45] Salazar A, Corbella X, Sánchez JL, Argimón JM, Escarrabill J. How to manage the ED crisis when hospital and/or ED capacity is reaching its limits. Report about the implementation of particular interventions during the Christmas crisis. Eur J Emerg Med. 2002; 9: 79-80. http://dx.doi.org/10.1097/00063110-200203000-00019

[46] DeCoster C, Peterson S, Carriere KC, Kasian P. Assessing the extent to which hospitals are used for acute care purposes. Med Care. 1999; 37(6 Suppl): JS151-166. PMid:10409007 http://dx.doi.org/10.1097/00005650-199906001-00014

[47] Bagust A, Place M, Posnett JW. Dynamics of bed use in accommodating emergency admissions: stochastic simulation model. BMJ. 1999; 319: 155-158. PMid:10406748 http://dx.doi.org/10.1136/bmj.319.7203.155

[48] Juan A, Salazar A, Alvarez A, Perez JR, Garcia L, Corbella X. Effectiveness and safety of an emergency department short-stay unit as an alternative to standard inpatient hospitalisation. Emerg Med J. 2006; 23: 833-837. PMid:17057132 http://dx.doi.org/10.1136/emj.2005.033647

[49] Salazar A, Juan A, Ballbe R, Corbella X. Emergency short-stay unit as an effective alternative to in-hospital admission for acute chronic obstructive pulmonary disease exacerbation. Am J Emerg Med. 2007; 25: 486-487. PMid:17499678 http://dx.doi.org/10.1016/j.ajem.2007.03.010

[50] Gomez-Vaquero C, Salazar Soler A, Juan Pastor A, Perez Mas JR, Jacob Rodriguez J, Corbella Viros X. Efficacy of a holding unit to reduce access block and attendance pressure in the emergency department. Emerg Med J. 2009; 26: 571-572. PMid:19625552 http://dx.doi.org/10.1136/emj.2008.066076

[51] Ortiga B, Capdevila C, Salazar A, Viso MF, Bartolomé C, Corbella X. Effectiveness of a Surgery Admission Unit for patients undergoing major elective surgery in a tertiary university hospital. BMC Health Serv Res. 2010 Jan 22; 10: 23. PMid:20096114 http://dx.doi.org/10.1186/1472-6963-10-23

[52] Schull MJ, Slaughter PM, Redelmeier DA. Urban emergency department overcrowding: defining the problem and eliminating misconceptions. CJEM. 2002; 4: 76-83. PMid:17612424

[53] Formiga F, Vidaller A, Salazar A, Pujol R. Functional decline in nonagenarians after a visit to an ED. Am J Emerg Med. 2003; 21: 509. http://dx.doi.org/10.1016/S0735-6757(03)00176-1

[54] Wilson MJ, Siegel B, Williams M. Perfecting patient flow: America's safety net hospitals and emergency department crowding [Internet]. The George Washington University Medical Center, May 2005. A report commissioned by the National Association of Public Hospitals and Health Systems. Available from: www.urgentmatters.org/media/file/reports_NAPH_Perfecting_Patient_Flow.pdf on January 2012.

[55] Managing acute patient flows [Internet]. Victorian Auditor-General's report, November 2008. Melbourne: Victorian Government Printer, 2008. Available from: www.audit.vic.gov.au/reports_publications/reports_by_year/2008/20081112_patient_flows.aspx on June 2011.

[56] Optimizing Patient Flow: Moving Patients Smoothly Through Acute Care Settings [Internet]. IHI Innovation Series white paper. Boston: Institute for Healthcare Improvement; 2003. Available from: www.ihi.org/knowledge/Knowledge $\% 20 \mathrm{Center} \% 20 \mathrm{Assets} /$ IHIWhitePapers\%20-\%20OptimizingPatientFlowMovingPatientsSmoothlyThrough AcuteCareSettings_768f4fcf-05e6-4893-b6eb-bedb14536dae/OptimizingPatientFlow White Paper2003.pdf on January 2012.

[57] NHS Modernisation Agency. 10 High impact changes for service improvement and delivery: a guide for NHS leaders [Internet]. Leicester, September 2004. Available from: www.anaesthesiaconference.kiev.ua/Downloads/HIC_for_web_2004.pdf on October 2011.

[58] Litvak E, ed. Managing Patient Flow in Hospitals: Strategies and Solutions. 2nd ed. Joint Commission Resources; 2009.

[59] Greene J. Emergency department flow and the boarded patient: how to get admitted patients upstairs. Ann Emerg Med. 2007; 49: 68-70. PMid:17203541 http://dx.doi.org/10.1016/j.annemergmed.2006.11.020

[60] Walters EH, Dawson DJ. Whole-of-hospital response to admission access block: the need for a clinical revolution. Med J Aust. 2009; 191: 561-563. PMid:19912090

[61] Wong HJ, Morra D, Caesar M, Carter MW, Abrams H. Understanding hospital and emergency department congestion: an examination of inpatient admission trends and bed resources. CJEM. 2010; 12: 18-26. PMid:20078914

[62] Richardson DB. The access-block effect: relationship between delay to reaching an inpatient bed and inpatient length of stay. Med J Aus. 2002; 177: 492-495. PMid:12405891 
[63] Dunn R. Reduced access block causes shorter emergency department waiting times: An historical control observational study. Emerg Med (Aust). 2003; 15: 232-238. http://dx.doi.org/10.1046/j.1442-2026.2003.00441.x

[64] Forster AJ, Stiell I, Wells G, Lee AJ, van Walraven C. The effect of hospital occupancy on emergency department length of stay and patient disposition. Acad Emerg Med. 2003; 10: 127-133. PMid:12574009 http://dx.doi.org/10.1111/j.1553-2712.2003.tb00029.x

[65] Moloney ED, Smith D, Bennett K, O'riordan D, Silke B. Impact of an acute medical admission unit on length of hospital stay, and emergency department 'wait times'. QJM. 2005; 98: 283-289. PMid:15760924 http://dx.doi.org/10.1093/qjmed/hci044

[66] Bain CA, Taylor PG, Mcdonell G, Georgiou A. Myths of ideal hospital occupancy. Med J Aust. 2010; 192: 42-43. PMid:20047548

[67] Cameron P, Scown P, Campbell D. Managing access block. Aust Health Rev. 2002; 25: 59-68. PMid:12404967 http://dx.doi.org/10.1071/AH020059

[68] Miró O, Sánchez M, Espinosa G, Coll-Vinent B, Bragulat E, Millá J. Analysis of patient flow in the emergency department and the effect of an extensive reorganisation. Emerg Med J. 2003; 20: 143-148. PMid:12642527 http://dx.doi.org/10.1136/emj.20.2.143

[69] Daly S, Campbell DA, Cameron PA. Short-stay units and observation medicine: a systematic review. Med J Aust. 2003; 178: 559-563. PMid:12765504

[70] Rooney T, Moloney ED, Bennett K, O'Riordan D, Silke B. Impact of an acute medical admission unit on hospital mortality: a 5-year prospective study. QJM. 2008; 101: 457-465. PMid:18319292 http://dx.doi.org/10.1093/qjmed/hcn025

[71] Salazar A, Estrada C, Porta R, Lolo M, Tomas S, Alvarez M. Home hospitalization unit: an alternative to standard inpatient hospitalization from the emergency department. Eur J Emerg Med. 2009; 16: 121-123. PMid:19262397 http://dx.doi.org/10.1097/MEJ.0b013e32831cbae2

[72] Scott I, Vaughan L, Bell D. Effectiveness of acute medical units in hospitals: a systematic review. Int J Qual Health Care. 2009; 21: 397-407. PMid:19903756 http://dx.doi.org/10.1093/intqhc/mzp045 